\title{
Effect of Compressive Deformations on the Final Microstructure of a Low Carbon High Silicon Bainitic Steel Thermomechanically Processed
}

\author{
Rodrigo Afonso Hatwiga* (1), Juan Dong ${ }^{b}$, Jérémy Epp ${ }^{b}$, Alexandre da Silva Rocha ${ }^{a}$ (1) \\ ${ }^{a}$ Universidade Federal do Rio Grande do Sul - UFRGS, Porto Alegre, Rio Grande do Sul, Brasil \\ ${ }^{b}$ Universität Bremen, Leibniz-Institut für Werkstofforientierte Technologien - IWT Bremen, Bremen, \\ Germany
}

Received: July 30, 2020; Revised: October 09, 2020; Accepted: November 27, 2020

\begin{abstract}
Due to a combination of advantages, high-performance steel components, especially for automotive manufacturing applications, are generally forged parts. In the forging industry, bainitic steels are being increasingly used, because they can reduce the processing chain and energy consumption. In this case, the bainitic microstructure can be obtained immediately after forging, with controlled cooling, and without any subsequent heat treatment. In the present work, the effect of thermomechanical routes performed in the austenitic and bainitic fields on the final microstructure and final hardness of $18 \mathrm{MnCrSiMo6}-4$ bainitic steel has been discussed. Thermomechanical processing routes were tested and evaluated in a Gleeble ${ }^{\circledR} 3800$ testing machine with one and two-step deformation. In both cases, the sample had its height reduced by $40 \%$ and the strain rate used was $0.1 \mathrm{~s}^{-1}$. It could be shown that the plastic deformation promoted in the bainite field induces the bainite transformation. The results also show a strong dependence of bainite morphology concerning the deformation temperature of the steel. Moreover, the knowledge of the hot and warm stress-strain curves is an important result because it allows estimating the necessary stress and the energy consumption per volume unit to deform the material.
\end{abstract}

Keywords: thermomechanical treatment; energy saving; bainitic steel.

\section{Introduction}

In the last decades, the excessive consumption of natural resources already has visible consequences throughout the planet. This fact, associated with current governmental requirements, such as the current Rota $2030^{1}$ and the National Action Plan on Energy Efficiency - NAPE $E^{2}$ programs, has led industries to implement a more efficient production system, with the rational use of these resources at all stages of manufacturing processes.

Thus, research projects related to the forging process have been ranking energy-saving by eliminating heat treating processes and developing forging thermomechanical treatments - such as the joint program AiF-DFG EcoForge ${ }^{3}$ and the international cooperation project BRAGECRIM, entitled "Energy-efficient manufacturing chain for advanced bainitic steels based on thermomechanical processing" 4. In this sense, processes such as direct quenching associated with the use of new materials - such as new bainitic steels ${ }^{5,6}$ - appear as an alternative to reduce energy waste.

The chemical composition of the new bainitic steels appears to be promising for applications in forging processes since they have a great potential to reduce the forged parts processing chain and save energy ${ }^{7-13}$. In the new bainitic forging steels the $\mathrm{C}$ content is limited around $0.2 \mathrm{wt}-\%$ to avoid welding problems ${ }^{14}$. The $\mathrm{C}$ and Mn decrease the Bs-temperature (which has a microstructural refinement

*e-mail: rodrigo.hatwig@ufrgs.br effect) but, according to Caballero et al. ${ }^{15}$, Mn segregations need to be avoided to suppress the martensite formation and mechanical properties deterioration. The Si effect is well established retarding the bainite kinetics, stabilizing the remaining austenite by carbon enrichment, and hence to suppression of cementite during bainite formation. Mo and $\mathrm{Cr}$ increase the hardenability, allowing a wider range of cooling rates may be employed.

The bainitic microstructure is well known for the adequate balance of mechanical and metallurgical properties, such as hardness and toughness. As shown in Caballero et al. ${ }^{16,17}$, impact toughness evaluation of different continuously cooled cementite-free bainitic microstructures demonstrated that bainitic microstructure consisting of lath-like upper bainite exhibits higher impact toughness values than those with a granular bainite morphology. In this sense, to achieve the bainitic microstructure and desired properties, the processing window should be investigated to find the best processing parameters for each application.

In this work, alternative thermomechanical processing routes to the traditional quenching/tempering processes and "classical" isothermal treatment were tested and evaluated. The main objectives of this work are: (i) determination of the warm and hot stress-strain curves, with emphasis on the ultimate compressive stress required to promote material deformation at a respective strain temperature; (ii) evaluation of the final microstructural condition of the steel regarding its morphology and hardness. 
Thermomechanical experiments were conducted with the $18 \mathrm{MnCrSiMo6}-4$ bainitic steel. Deformations on the austenitic and bainitic fields were performed with subsequent direct and controlled cooling after compressive deformation. In this way, the influence of the different processing routes is analyzed, and more knowledge was obtained about the bainitic microstructure formation.

\section{Experimental Procedure}

\subsection{Investigated material}

The 18MnCrSiMo6-4 (1.801, HSX 130HD) steel on its original condition (as received) was $\varnothing 43 \mathrm{~mm}$, hot rolled and cooled by natural air cooling $\left(\sim 1^{\circ} \mathrm{C} / \mathrm{s}\right)$. The chemical composition is shown in Table 1.

The microstructure of the material as received consists mainly of the bainitic phase and with a small volumetric fraction of pro-eutectoid ferrite. Figure 1 presents the microstructure of the material as received.

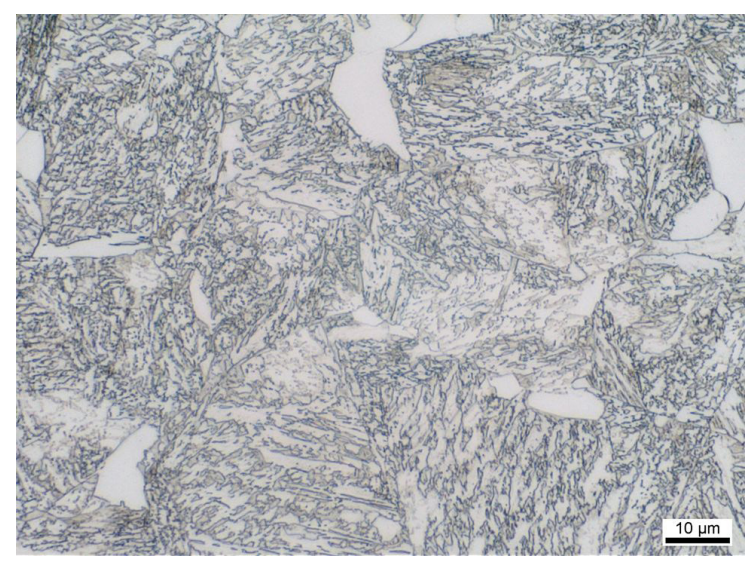

Figure 1. Microstructure of the $18 \mathrm{MnCrSiMo6}-4$ bainitic steel as received.

\subsection{Thermomechanical routes}

Figure 2 shows a Gleeble ${ }^{\circledR} 3800$ universal testing machine used to perform the alternative processing routes presented in Figures 3-7.

The strain rate of $0.1 \mathrm{~s}^{-1}$ was used to apply the deformations at temperatures of $950{ }^{\circ} \mathrm{C}, 850{ }^{\circ} \mathrm{C}$, and $500^{\circ} \mathrm{C}$. Moreover, the deformation temperatures and cooling rates were defined based on the CCT diagram of the material under study and defined according to industrial applications. All process parameters used to perform the experiments can be seen directly in Figures 3-8.

Thus, the processing routes represented in Figures 3-7 were tested to obtain more in-depth knowledge about the final properties of the material under these specific processing conditions. The similarity of these tests with the forging process is regarding the stress state and the limitation is the maximum strain rate to be applied. Besides that, valuable information can be gained to adequate processing of this material on industrial scale.

The tests used cylinder-shaped samples of the material under study, with the following dimensions: $10 \mathrm{~mm}$ (diameter) x $15 \mathrm{~mm}$ (height) which were deformed: (i) in a single step, until $40 \%$ of its original height, and (ii) in combined steps, $20 \%+20 \%$ in the austenitic field and $20 \%$ in the austenitic $+20 \%$ in the bainitic field.

The samples of the thermomechanical processing routes represented by Figures 5 and 7 were deformed in two distinct stages. Firstly, a deformation degree of $20 \%$ was performed in the austenitic field. For the second stage, another $20 \%$ deformation now in the low austenitic temperature and bainitic fields were performed taking as reference the sample height after the first deformation step.

Table 2 summarizes the range of tests performed, together with the parameters used.
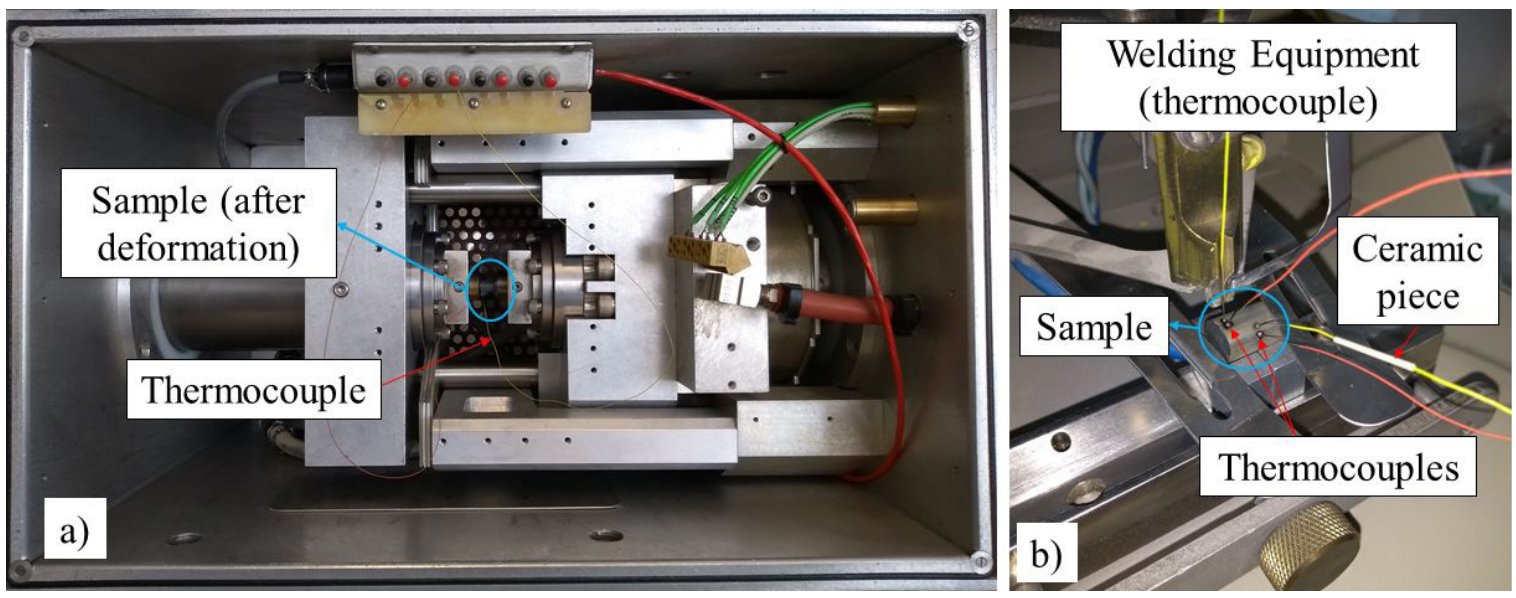

Figure 2. Gleeble ${ }^{\circledR} 3800$ universal testing machine details a), and the welding equipment used to weld thermocouples in the sample b).

Table 1. Chemical composition (mass- $\%$, balance: $\mathrm{Fe}$ ) of the $18 \mathrm{MnCrSiMo6}-4$ steel.

\begin{tabular}{ccccccccc}
\hline Steel Grade & $\mathrm{C}$ & $\mathrm{Mn}$ & $\mathrm{Si}$ & $\mathrm{Cr}$ & $\mathrm{Mo}$ & $\mathrm{P}$ & $\mathrm{S}$ & $\mathrm{Fe}$ \\
\hline $\mathbf{1 8 M n C r S i M o 6 - 4}$ & 0.17 & 1.48 & 1.22 & 1.2 & 0.27 & 0.011 & 0.015 & Balance \\
\hline
\end{tabular}




\section{Results and Discussion}

\subsection{Stress-Strain curves}

In conventional hot and warm forging, the billet is heated up to its respective forging temperature to reduce yield stress

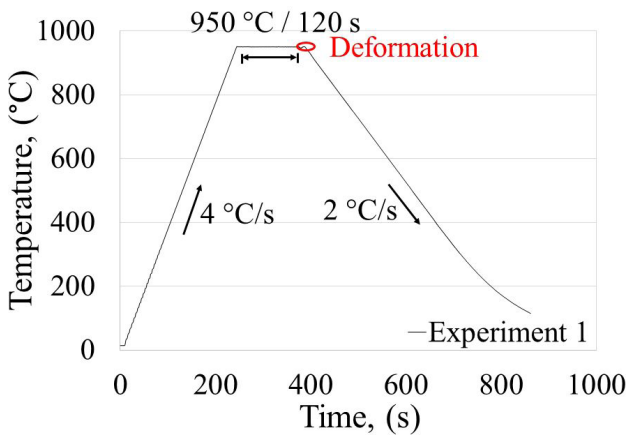

Figure 3. Thermomechanical route with a deformation degree of $40 \%$ in the austenitic field at $950{ }^{\circ} \mathrm{C}$, and applied strain rate of $0,1 \mathrm{~s}^{-1}$.

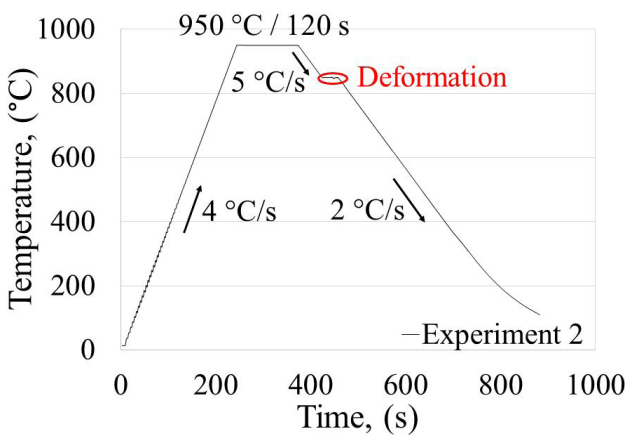

Figure 4. Thermomechanical route with a deformation degree of $40 \%$ in the austenitic field at $850{ }^{\circ} \mathrm{C}$, and applied strain rate of $0,1 \mathrm{~s}^{-1}$.

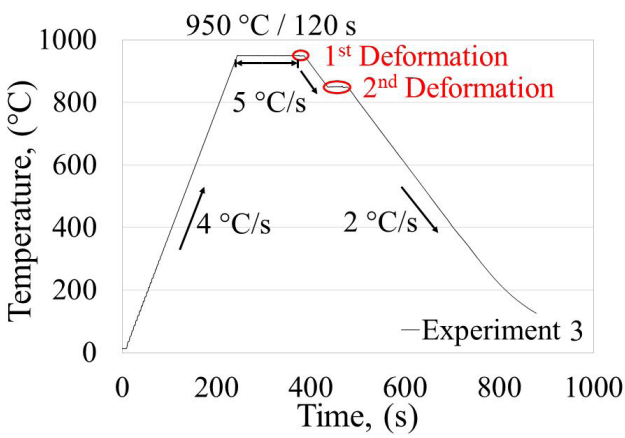

Figure 5. Thermomechanical route with two steps deformation at: $950{ }^{\circ} \mathrm{C}(20 \%)+850{ }^{\circ} \mathrm{C}(20 \%)$, and applied strain rate of $0.1 \mathrm{~s}^{-1}$. and increase deformability. However, forging industry has a big interest in quantifying the stress required to carry out the forging and, thus, to predict operating costs. Figure 8 shows the stress-strain curves of $18 \mathrm{MnCrSiMo6}-4$ steel after deformations at temperatures of $950{ }^{\circ} \mathrm{C}, 850{ }^{\circ} \mathrm{C}$, and $500{ }^{\circ} \mathrm{C}$ obtained after applying the parameters showed in Table 2. The two-step deformations (experiments 3 and 5) follow the below curves up to a strain of 0.2 .

As the strain rate is constant, the stress increases as the strain increases, reaching a steady state characteristic of the elastoplastic deformation. As expected, the material exhibits lower mechanical strength values as the deformation temperature increases. The high stress necessary (up to 4 times) to promote deformation in the bainitic field becomes evident regarding the deformations promoted in the austenitic field. This fact is associated with the bainitic transformation induced by the deformation, besides the higher strength of the metastable austenite at a lower temperature.

In hot deformation, the flow stress is mainly dependent on strain rate and deformation temperature and, as the strain

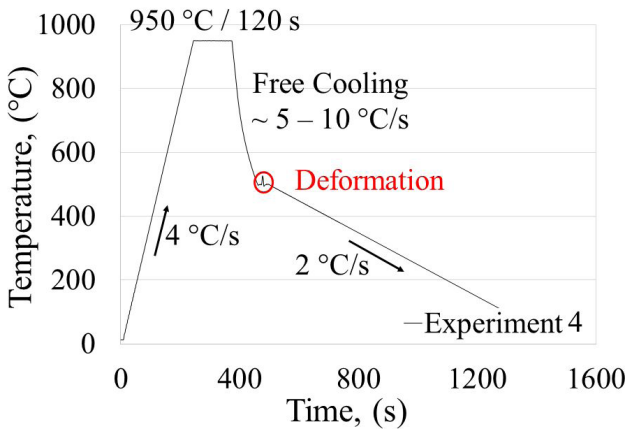

Figure 6. Thermomechanical route with a deformation degree of $40 \%$ in the bainitic field at $500{ }^{\circ} \mathrm{C}$, and applied strain rate of $0.1 \mathrm{~s}^{-1}$.

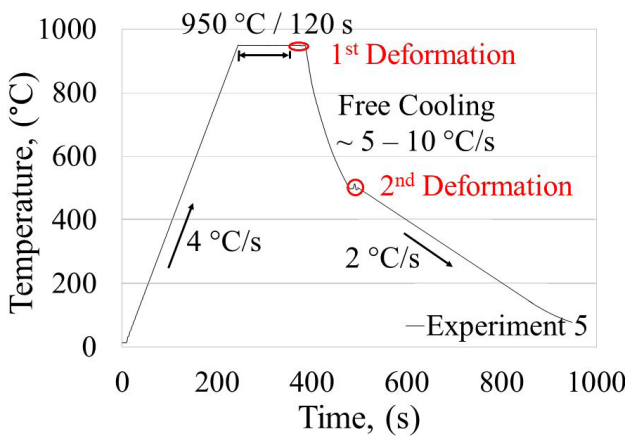

Figure 7. Thermomechanical route with two steps deformation: $950{ }^{\circ} \mathrm{C}(20 \%)+500{ }^{\circ} \mathrm{C}(20 \%)$, and applied strain rate of $0.1 \mathrm{~s}^{-1}$.

Table 2. Tests and parameters used in the implementation of thermomechanical routes.

\begin{tabular}{ccccccc}
\hline Experiment & $\begin{array}{c}\mathbf{A T} \\
\left({ }^{\circ} \mathbf{C}\right)\end{array}$ & $\begin{array}{c}\text { At } \\
(\mathbf{s})\end{array}$ & $\begin{array}{c}\text { DT } \\
\left({ }^{\circ} \mathbf{C}\right)\end{array}$ & $\begin{array}{c}\text { Deformation } \\
\text { Degree, }(\mathbf{\%})\end{array}$ & $\begin{array}{c}\text { Cooling Rate, } \\
\left({ }^{\circ} \mathbf{C} / \mathbf{s}\right)\end{array}$ & $\begin{array}{c}\text { Strain Rate, } \\
\left(\mathbf{s}^{-1}\right)\end{array}$ \\
\hline $\mathbf{1}$ & 950 & 120 & 950 & 40 & 2 & 0.1 \\
\hline $\mathbf{2}$ & 950 & 120 & 850 & 40 & 2 & 0.1 \\
\hline $\mathbf{3}$ & 950 & 120 & $950 / 850$ & $20+20$ & $5-10\left(1^{\text {st }}\right.$ step $) / 2\left(2^{\text {nd }}\right.$ step $)$ & 0.1 \\
\hline $\mathbf{4}$ & 950 & 120 & 500 & 40 & 2 & 0.1 \\
\hline $\mathbf{5}$ & 950 & 120 & $950 / 500$ & $20+20$ & $5-10\left(1^{\text {st }}\right.$ step $) / 2\left(2^{\text {nd }}\right.$ step $)$ & 0.1 \\
\hline
\end{tabular}

AT: austenitization temperature; At: austenitization time; DT: deformation temperature. The samples of experiments 4 and 5 (Figures 6-7) cooled freely in vacuum without temperature regulation. The cooling rate obtained (within $5-10^{\circ} \mathrm{C} / \mathrm{s}$ ) was enough to suppress the pre-eutectoid ferrite formation. 
rate and the temperature were kept constant during the test, the adjustment corresponding to the Ludwik-Hollomon (Equation 1), was chosen. This equation is the most common equation to describe the material flow behavior, which the flow curve gives the stress, $k_{f}$, necessary for plastically flow of the material under a given strain $\varphi$. The factor $C$ is the strength coefficient and $n$ the strain hardening exponent.

$\mathrm{K}_{\mathrm{f}}=$ C. $\varphi^{\mathrm{n}}$

Table 3 shows the characterization of the flow stress-strain curves according to Ludwik-Hollomon equation.

In this way, through Equation 1 it is possible to obtain the stress to promote deformations up to $\varphi=0.4$. Many parameters affect the material's formability. Among them, the superficial defects in the piece have a limiting factor. In the deformation's conditions employed no cracks

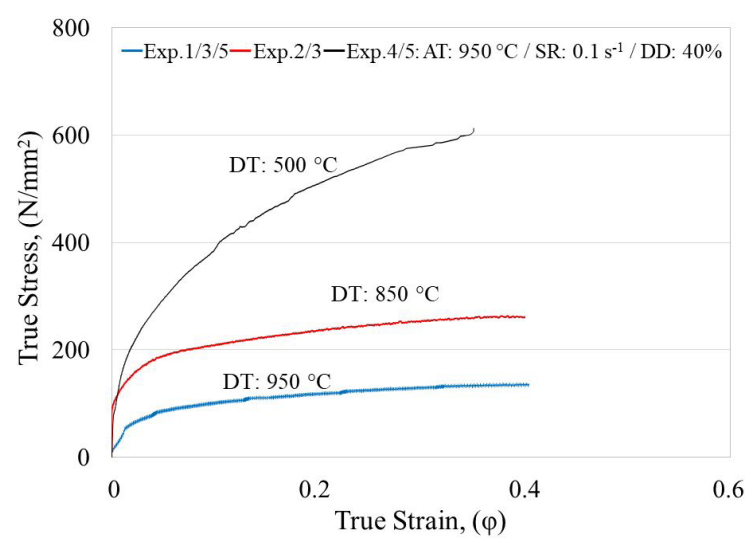

Figure 8. Hot and warm stress-strain curves of the 18MnCrSiMo6-4 steel obtained after one-step deformation in the austenitic and bainitic fields. * AT: austenitization temperature; DT: deformation temperature; DD: deformation degree.

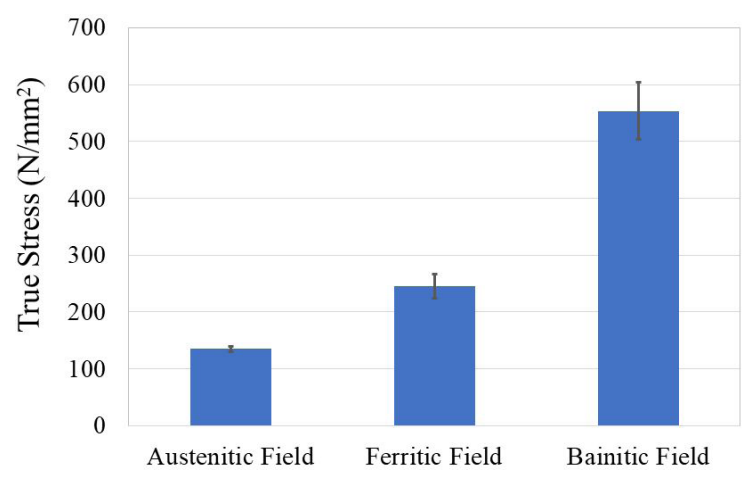

Figure 9. Ultimate compressive strength to promote hot deformation of $18 \mathrm{MnCrSiMo6}-4$ steel under the tested conditions. were observed in the samples. However, not just the formability must be considered. There are works, such as $^{16,18}$ that discuss mechanical properties obtained at room temperature through bainitic microstructures in steels with similar applications to $18 \mathrm{MnCrSiMo6}-4$ steel, that shows a strong dependence of the toughness, strength, and hardness of the microstructure.

Figure 9 shows the ultimate compressive strength values required to deform the material under the test conditions described in Table 2.

\subsection{Metallographic analysis}

Figures 10-13 show the microstructures related to the performed physical simulation experiments. In this case, the metallographic analysis shows the final microstructural condition of the sample tested; i. e., the refining of the microstructure and its constituents. Therefore, it is possible to project the final mechanical properties of the forged component regarding the thermomechanical route employed. In work of Caballero et al. ${ }^{16}$ microstructural characterization and impact toughness evaluation of different continuously cooled cementite free low carbon bainitic steels have demonstrated that bainitic microstructures formed mainly by lath-like bainite exhibit higher impact toughness values than those with a granular bainite morphology. The larger crystallographic packet size of granular bainite shows evidence of low resistance to crack propagation during cleavage fracture.

In the deformed sample at $950{ }^{\circ} \mathrm{C}$, Figure $10 \mathrm{a}, \mathrm{b}$, the microstructure consists of lath-like bainite and small amount of pre-eutectoid ferrite. This microstructure is associated with the high density of dislocations generated in the deformed austenite and, at lower austenitization temperatures, recovery and recrystallization mechanisms are difficult to happen. Thus, the formation of a high-density of dislocations in austenite will suppress the ferrite transformation, which occur by shear mechanism. Similar results were found by the authors ${ }^{19,20}$ and, according to ${ }^{21}$, the high density of defects is considered as one of the main reasons for the stabilization of deformed austenite.

Samples deformed at $850{ }^{\circ} \mathrm{C}$, Figure $11 \mathrm{a}, \mathrm{b}$, shows a large amount of pre-eutectoid ferrite and lath-like bainite in the microstructure. When the deformation temperature decreases, a large amount of ferrite will precipitate, and the deformation now has stabilized effects on bainite transformation. It means that the subsequent transformation of bainite will be hindered, in agreement with the results obtained by Lin-xiu et al. ${ }^{19}$.

On the other hand, the formation of the ferritic phase leads to an increase in the carbon content of untransformed austenite and this fact has a dual effect. According to Khlestov et al. ${ }^{20}$ in the upper range of bainite, carbon has a destabilization effect in deformed austenite, in which it

Table 3. Stress-Strain curves parameters according to Ludwik-Hollomon equation.

\begin{tabular}{lcccc}
\hline \multicolumn{1}{c}{ Experiment } & $\mathrm{C}$ & $\mathrm{n}$ & $\varphi$ & $\mathrm{R}^{2}$ \\
\hline 1. TA: $950^{\circ} \mathrm{C} / \mathrm{TD}: 950^{\circ} \mathrm{C}(40 \%)$ & 173 & 0.2381 & 0.4 & 0.990 \\
\hline $\mathbf{2 .} \mathrm{TA}: 950^{\circ} \mathrm{C} / \mathrm{TD}: 850^{\circ} \mathrm{C}(40 \%)$ & 317 & 0.2642 & 0,4 & 0.994 \\
\hline 4. TA: $950^{\circ} \mathrm{C} / \mathrm{TD}: 500^{\circ} \mathrm{C}(40 \%)$ & 911 & 0.3737 & 0.35 & 0.997 \\
\hline
\end{tabular}


will enhance the acceleration effects of deformation on the bainite transformation. The opposite phenomenon occurs in the lower range of bainite, when the increase in carbon content stabilize the untransformed austenite which can be transformed in martensite. This way, the increase in carbon content makes the bainitic reaction more difficult.

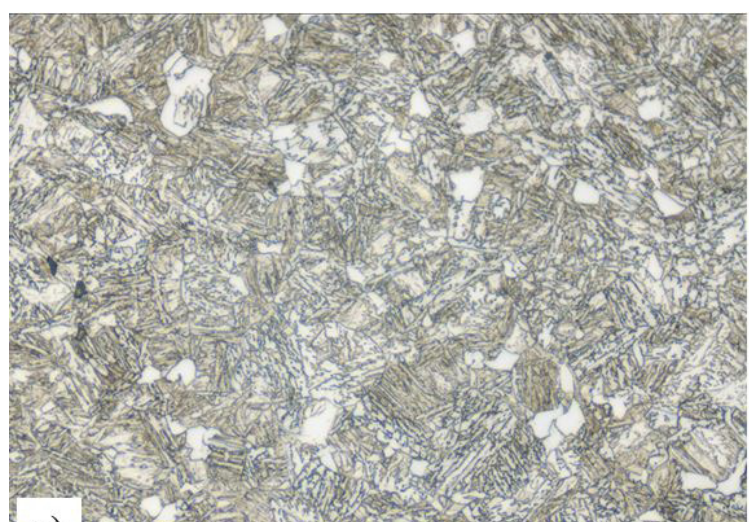

a)

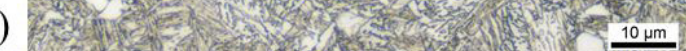

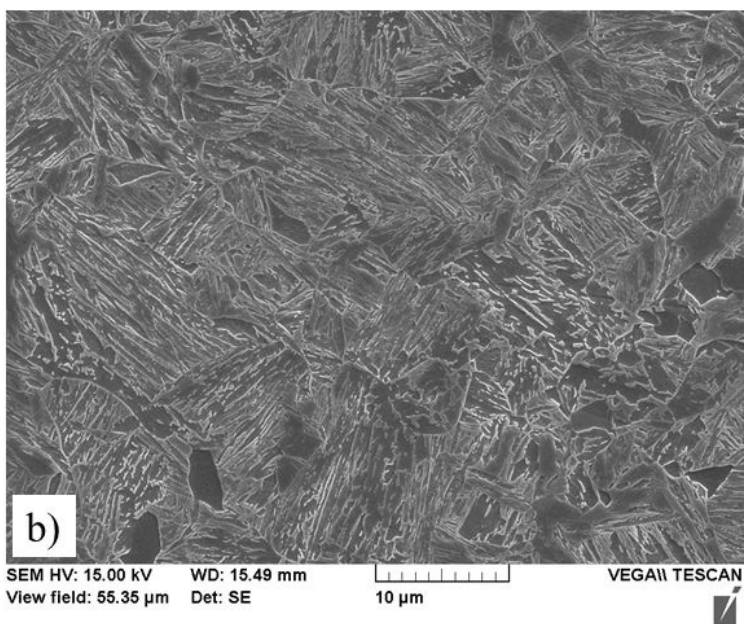

Figure 10. Final microstructure corresponding to the thermomechanical treatment of Experiment 1 - AT: $950{ }^{\circ} \mathrm{C} / \mathrm{DT}$ : $950{ }^{\circ} \mathrm{C}$. (a) optical microscopy, (b) scanning electron microscopy.
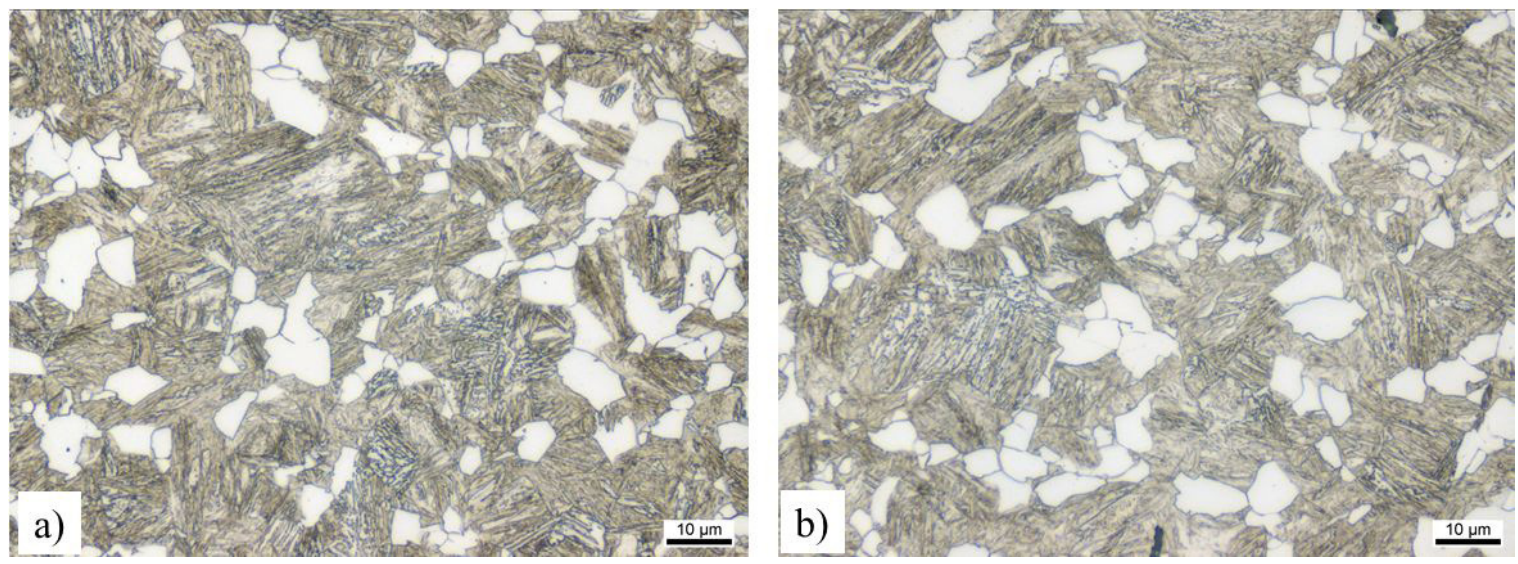

Figura 11. Final microstructure corresponding to the hermomechanical treatment of (a) Experiment 2 - AT: $950{ }^{\circ} \mathrm{C} / \mathrm{DT}$ : $850{ }^{\circ} \mathrm{C}$ - onestep deformation, and (b) Experiment 3 - AT: $950{ }^{\circ} \mathrm{C} / \mathrm{DT}$ : $950{ }^{\circ} \mathrm{C} \_850{ }^{\circ} \mathrm{C}$ - two-step deformation.
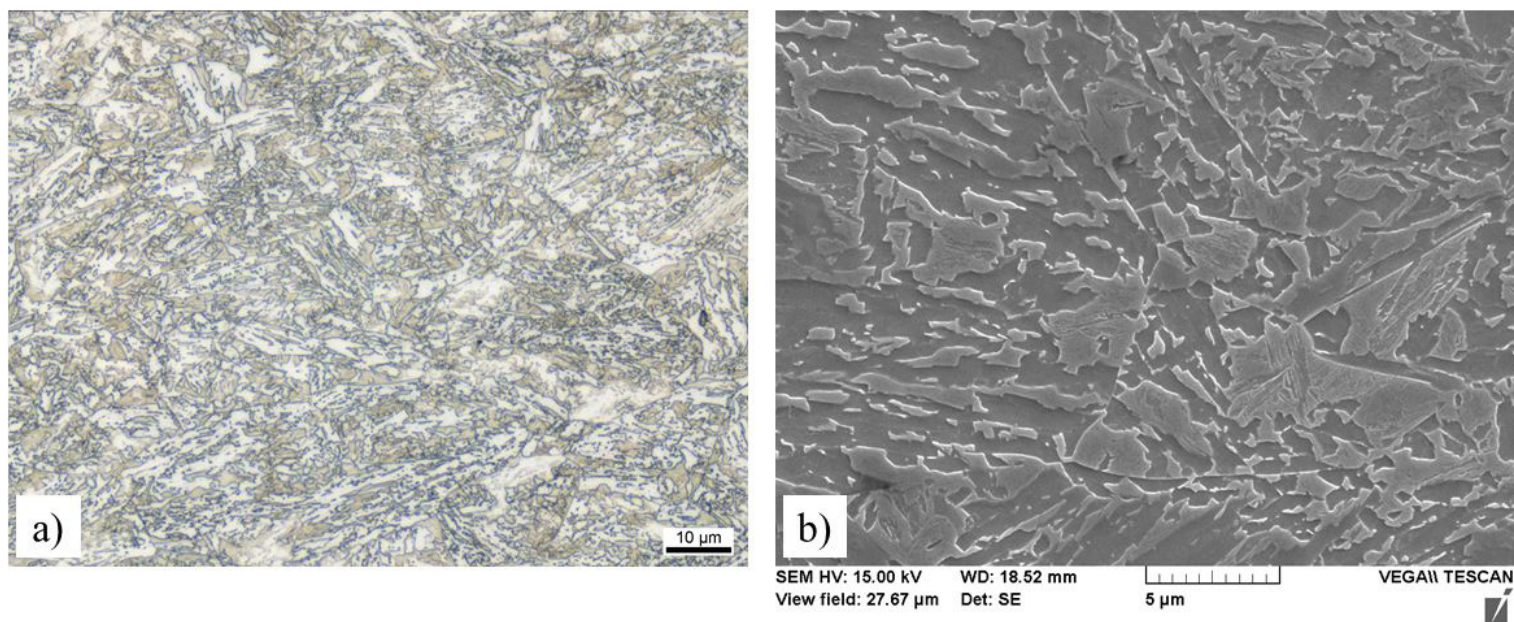

Figura 12. Final microstructure corresponding to the thermomechanical treatment of Experiment 4 - AT: $950{ }^{\circ} \mathrm{C} / \mathrm{DT}$ : $500^{\circ} \mathrm{C}$. (a) optical microscopy, (b) scanning electron microscopy. 


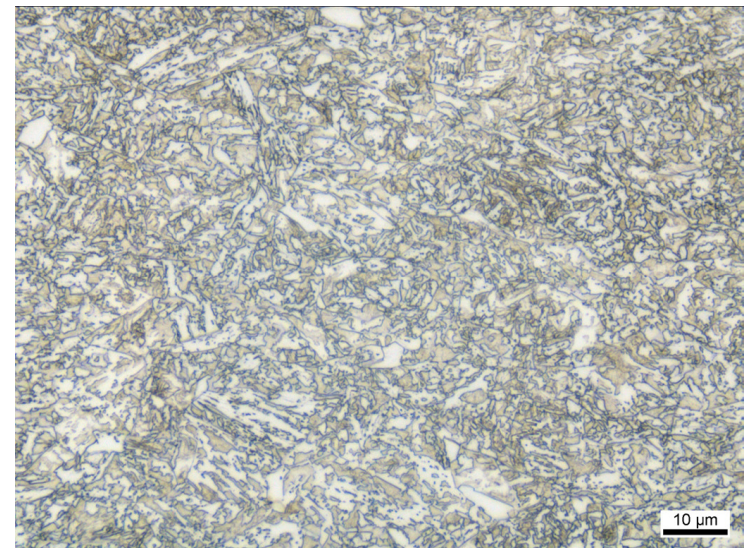

Figura 13. Final microstructure corresponding to the thermomechanical treatment of Experiment 5 -AT: $950^{\circ} \mathrm{C} / \mathrm{DT}: 950^{\circ} \mathrm{C} \_500^{\circ} \mathrm{C}-t w o-$ step deformation.

Table 4. Final hardness of samples obtained through thermomechanical routes.

\begin{tabular}{ll}
\hline \multicolumn{1}{c}{ Experiment } & $\begin{array}{c}\text { Hardness } \\
\text { (HV 1) }\end{array}$ \\
\hline 1. TA: $9500^{\circ} \mathrm{C} / \mathrm{TD}: 950{ }^{\circ} \mathrm{C}(40 \%)$ & $388 \pm 13$ \\
\hline 2. TA: $950{ }^{\circ} \mathrm{C} / \mathrm{TD}: 850{ }^{\circ} \mathrm{C}(40 \%)$ & $377 \pm 11$ \\
\hline 3. TA: $950{ }^{\circ} \mathrm{C} / \mathrm{TD}: 950{ }^{\circ} \mathrm{C}(20 \%)+850{ }^{\circ} \mathrm{C}(20 \%)$ & $384 \pm 4$ \\
\hline 4. TA: $9500^{\circ} \mathrm{C} / \mathrm{TD}: 500{ }^{\circ} \mathrm{C}(40 \%)$ & $391 \pm 6$ \\
\hline 5. TA: $950{ }^{\circ} \mathrm{C} / \mathrm{TD}: 950{ }^{\circ} \mathrm{C}(20 \%)+500{ }^{\circ} \mathrm{C}(20 \%)$ & $391 \pm 10$ \\
\hline *sample as received & $330 \pm 7$ \\
\hline
\end{tabular}

Deformation has several effects on the bainitic transformation which can retard or accelerate it. Thus, the parameters of the deformation and the transformation temperature have a great impact on the bainitic kinetics.

Figure 12a, b and Figure 13a show that the microstructure resulting from the experiment 4 and 5 consists mainly of granular bainite, martensite, and retained austenite. Deformation at $500{ }^{\circ} \mathrm{C}$ leads to the formation of granular bainite and stabilizes the deformed austenite, which transformed later in martensite. Microscopically, it has no difference if the deformation is promoted in one or two-steps. The presence of a hard phase, such as martensite, in a bainitic microstructure, would be undesired because they could be detrimental to toughness.

\subsection{Hardness}

Table 4 shows the final hardness of the samples in relation to the thermomechanical route employed. There was no big variation in the hardness of the samples submitted to the different thermomechanical treatments. However, the pre-eutectoid ferritic phase slightly decreases the hardness of the material, which is directly related to its volumetric fraction in the material, as seen in experiments 2 and 3 . The fact that the hardness of bainite increases linearly with the carbon concentration ${ }^{22}$, associated with the presence of the martensitic phase justifies the small increase in the average hardness values of the samples from experiments 4 and 5 .

However, refining bainitic microstructure and work hardening increased $20 \%$ the final hardness compared to the sample as received. Finally, despite the different morphologies of bainite, according to Kamada et al. ${ }^{23}$, the final hardness of the bainitic phase is independent of the austenite grain size, even though the latter influences the bainite sheaf thickness and the strength. For mixed microstructures, the hardness depends on the transformation temperature and composition.

\section{Conclusions}

The present study contains results of the effects of metastable austenite deformation on the final morphology of the phase transformation, especially the bainitic phase, as well as mechanical properties. These data are of practical importance for the selection of optimum thermomechanical processing conditions applicable on an industrial scale. The major conclusions are drawn from the present investigation:

- The deformation temperature has a critical effect on the bainitic transformation and its morphology. High deformation temperatures suppress the pro-eutectoid ferrite formation and favor the transformation of deformed austenite into bainite. Deformations at lower austenitization temperatures will form preeutectoid ferrite and it has a big influence on further phase transformations. Thus, deformation at higher temperatures should be preferred, because it has the best balance between the final microstructure (lath like bainite) and energy consumption.

- The final microstructure of samples deformed in the bainitic field (one or two stages) is more refined. However, the large size of granular bainite packets and martensite has a detrimental effect on the mechanical properties, in addition to consuming more energy in the deformation according with the stress-strain curves.

- The results indicate a great potential for the use and application of new continuous cooling bainitic steels because subsequent heat treating, such as quenching and tempering, can be substituted by adequate forging strategies and controlled cooling.

\section{Acknowledgment}

The authors acknowledge the Coordenação de Aperfeiçoamento de Pessoal de Nível Superior - Brasil (CAPES) for the support in the Bragecrim Program (project proc 1844/2017) and the Conselho Nacional de Desenvolvimento Científico e Tecnológico (CNPq) for the grants (scholarship proc. 167149/2017-2 and Pq-2018 grant proc. 142097/2015-2). The authors also acknowledge the Deutsche Forschungsgemeinschaft - DFG (project ZO 140/21-1) for the financial support.

\section{References}

1. Fi Group. O que é a rota 2030? [Internet]. 2020 [cited 2020 Jul 26]. Available from: https://www.rota2030.com.br/

2. Bundesministerium Für Wirtschaft und Energie [homepage on the Internet]. 2020 [cited 2020 Jul 26]. Available from: https:// www.bmwi.de/

3. Fischer M, Henning H-H, Bleck W, Huskic A, Kazhai M, Hadifi T, et al. EcoForge: Enerigeeffiziente Prozesskette zur Herstellung von Hochleistungs Schmiedebauteilen. HTM J. Heat Treat. Mater. 2014;69:209-19. 
4. Bragecrim/CRI-SCMfg [homepage on the Internet]. 2020 [cited $2020 \mathrm{Jul}$ 26]. Available from: http://www.bragecrim. rwth-aachen.de/

5. Buchmayr B. Critical assessment 22: bainitic forging steels. Materials Science and Technology (United Kingdom). 2016;32(6):1-6.

6. Bhadeshia HKDH. Bainite in steels theory and practice. 3rd ed. Inglaterra: Maney Publishing; 2015.

7. Sourmail T. Bainite and superbainite in long products and forged applications. HTM J. Heat Treat. Mat. 2017;72(6):371-8.

8. Hasler S. Bainitischer Stahl Swissbain-7MnB8 senkt Herstellkosten. Stahl Eisen. 2014;134(8):58-60.

9. Bhadeshia HKDH. Nanostructured bainite. P. Roy. Soc. A. 2010;466:3-18.

10. Roelofs H, Hasler S, Chabbi L, Urlau U, Chen J, Bhadeshia HKDH. Multiphase structures in case hardening steels following continuous cooling. In: The New Developments on Metallurgy and Applications of High Strength Steels; Buenos Aires; 2008. Proceedings. Hoboken: Wiley-TMS; 2008. p. 761-8. Vol. 2 - Physical Metallurgy and Alloy Design.

11. Eggbauer G, Buchmayr B. High-strength bainitic steels for forged products. Berg- und Hüttenmänn. Monatshefte. 2015;160(5):209-13.

12. Srivatsa K, Srinivas P, Balachandran G, Balasubramanian V. Room temperature microstructure and property evaluation of a heat treated fully bainitic 20CrMoVTiB410 steel. JOM. 2016;68:2704-12.

13. Xu Z, Hui W, Wang Z, Zhang Y, Zhao X, Zhao X. Mechanical properties of a microalloyed bainitic steel after hot forging and tempering. J Iron Steel Res Int. 2017;24:1085-94.
14. Bhadeshia HKDH. High performance bainitic steels. Materials Science Forum. 2005;500-501:63-74.

15. Caballero FG, Chao J, Cornide J, Garcia-Mateo C, Santofimia MJ, Capdevila C. Toughness deterioration in advanced high strength bainitic steels. Mater Sci Eng A. 2009;525:87-95.

16. Caballero FG, Capdevila C, Chao J, Cornide J, Garcia-Mateo $\mathrm{C}$, Roelofs $\mathrm{H}$, et al. The microstructure of continuously cooled tough bainitic steels. In: 2nd International ConferenceSuper high strength steel; 2010; Peschiera, Italy. Proceedings. Milano: Associazione Italiana di Metallurgia; 2010. p. 17-20.

17. Caballero FG, Roelofs H, Hasler S, Capdevila C, Chao J, Cornide $\mathrm{J}$, et al. Influence of bainite morphology on impact toughness of continuously cooled cementite free bainitic steels. Mater Sci Technol. 2012;28(1):95-102.

18. Eggbauer G, Buchmayr B. Optimized cooling strategies for bainitic forging steels. Key Eng Mater. 2016;716:472-80.

19. Lin-xiu DU, Hai-long YI, Hua DING, Xiang-hua LIU, Guodong WANG. Effects of deformation on bainite transformation during continuous cooling of low carbon steels. J Iron Steel Res Int. 2006;13(2):37-9.

20. Khlestov VM, Konopleva EV, Mcqueen HJ. Kinetics of austenite transformation during thermomechanical processes. Can Metall Q. 1998;37(2):75-89.

21. Kurdomov GV, Utevsky LM, Entin RI. Transformations in iron and steel. Moscow: Nauka; 1977.

22. Irvine KJ, Pickering FB. High carbon bainitic steels. In: The Iron and Steel Institute. Physical properties of martensite and bainite. London: The Iron and Steel Institute; 1965, p. 110-25. Special Report 93.

23. Kamada A, Koshizuka N, Funakoshi T. Effect of austenite grain size and $\mathrm{C}$ content on microstructure and toughness of tempered martensite and bainite. Trans. ISIJ. 1976;16:407-16. 